\title{
Methods in Enzymology
}

\section{Volume 97 \\ Biomembranes}

Part $K$

Membrane Biogenesis: Assembly and Targeting (Prokaryotes, Mitochondria, and Chloroplasts)

\section{EDITED BY}

Sidney Fleischer

Becca Fleischer

DEPARTMENT OF MOLECULAR BIOLOGY

VANDERBILT UNIVERSITY

NASHVILLE, TENNESSEE

Editorial Advisory Board

David Baltimore

Günter Blobel

Nam-Hai Chua
Walter Neupert

George Palade

David Sabatini

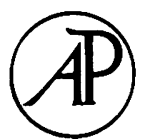

\section{ACADEMIC PRESS}

A Subsidiary of Harcourt Brace Jovanovich, Publishers

New York London

Paris San Diego San Francisco São Paulo Sydney Tokyo Toronto 


\section{Table of Contents}

Contributors To Volume 97 . . . . . . . . . . . . . . . . . . . . . . . . . . ix

Preface . . . . . . . . . . . . . . . . . . . . . . . . . . xiii

VOlUMES IN SeRIES. . . . . . . . . . . . . . . . . . . . . . . . $\mathrm{xV}$

\section{Section I. Prokaryotic Membranes}

\section{A. General Methods}

1. Genetic Analysis of Protein Export in Escherichia Jonathan Beckwith AND coli

Thomas J. Silhavy

2. Isolation and Characterization of Mutants of Escherichia coli $\mathrm{K} 12$ Affected in Protein Localization

ThOMAS J. Silhavy AND

JONATHAN BECKWITH

3. Purification and Characterization of Leader Peptidase from Escherichia coli

P. B. WOLFE, C. ZWIZINSKI, AND William WickNer

4. Molecular Genetics of Escherichia coli Leader Peptidase

Takayasu Date,

Pamela Silver, AND

WILLIAM WICKNER

5. Pulse-Labeling Studies of Membrane Assembly and Protein Secretion in Intact Cells: M13 Coat Protein

William Wickner,

Takayasu Date, RICHARD ZIMMERMANN, AND KOREAKI ITO

6. Synthesis of Proteins by Membrane-Associated Polysomes and Free Polysomes

PNang C. TAi, Michael P. Caulfield, AND BERNARD D. DAVIS

7. Preparation of Free and Membrane-Bound Polysomes from Escherichia coli

LINDA L. RANDALL AND

SIMON J. S. HARDY

8. Analysis of Cotranslational Proteolytic Processing of

LARS-GÖRAN JOSEFSSON Nascent Chains Using Two-Dimensional Gel and Linda L. RANDALL

Electrophoresis

\section{B. Outer Membrane}

9. Proteins Forming Large Channels from Bacterial

HIROSHI NIKAIDO and Mitochondrial Outer Membranes: Porins and Phage Lambda Receptor Protein

10. Phage $\lambda$ Receptor (LamB Protein) in Escherichia coli

Maxime Schwartz

11. Synthesis and Assembly of the Outer Membrane Proteins OmpA and OmpF of Escherichia coli

IAN CROWLeSMith AND KONRAD GAMON

12. Isolation of Mutants of the Major Outer Membrane Lipoprotein of Escherichia coli for the Study of Its Assembly

JaCk Coleman, SUMIKo INOUYE, AND MASAYORI INOUYE 


\section{Inner Membrane}

13. Analysis of M13 Procoat Assembly into Membranes in Vitro

COLIN WatTS,

Joel M. Goodman,

Pamela Silver, AND

WiLLIAM WiCKNER

14. Insertion of Proteins into Bacterial Membranes

Peter Model and

MARJORIE RUSSEL

15. Influence of Membrane Potential on the Insertion and Transport of Proteins in Bacterial Membranes

Robert C. LANDICK,

Charles J. Daniels, AND

DALE L. OXENDER

16. Penicillinase Secretion in Vivo and in Vitro

JeNNifer B. K. Nielsen

17. Lactose Permease of Escherichia coli

J. K. WRIGHT,

R. M. TEATHER, AND

P. OVERATH

18. Cloning of the Structural Genes of the Escherichia coli Adenosinetriphosphatase Complex

DAVID A. JANS AND

Frank GibSON

19. Biogenesis of an Oligomeric Membrane Protein Complex: The Proton Translocating ATPase of Escherichia coli

William S. A. Brusilow,

Robert P. Gunsalus, AND

ROBERT D. SIMONI

20. Analysis of Escherichia coli ATP Synthase Subunits by DNA and Protein Sequencing

JOHN E. WALKER AND

Nicholas J. GaY

21. Biogenesis of Purple Membrane in Halobacteria

DOROTHEA-CH.

Neugebauer,

HORST-PETER ZINGSHEIM, AND DieTER OESTERHELT

22. Isolation of the Bacterioopsin Gene by Colony $\mathrm{Hy}$ bridization

Heike Vogelsang,

WOLfGANG OERTEL, AND

Dieter Oesterhelt

\section{Section II. Mitochondria}

23. Assessing Import of Proteins into Mitochondria: An SUSAN M. GASSER AND Overview

RICK HAY

24. Molecular Cloning of Middle-Abundant mRNAs from Neurospora crassa

AdELHEID Viebrock,

Angela Perz, and

WALter Sebald

25. Biogenesis of Cytochrome $c$ in Neurospora crassa

BERND HENNIG AND

WALTER NEUPERT

26. Biosynthesis and Assembly of Nuclear-Coded Richard ZimmermanN Mitochondrial Membrane Proteins in Neurospora AND WALTER NEUPERT crassa 
27. Isolation and Properties of the Porin of the Outer Mitochondrial Membrane from Neurospora crassa

28. Synthesis and Assembly of Subunit 6 of the Mitochondrial ATPase in Yeast

29. Preparation and Use of Antibodies against Insoluble Membrane Proteins

30. Processing of Mitochondrial Polypeptide Precursors in Yeast

31. Pulse Labeling of Yeast Cells and Spheroplasts

32. Import of Polypeptides into Isolated Yeast Mitochondria

33. A Yeast Mitochondrial Chelator-Sensitive Protease That Processes Cytoplasmically Synthesized Protein Precursors: Isolation from Yeast and Assay

34. Selection and Characterization of Nuclear Genes Coding Mitochondrial Proteins: Genetic Complementation of Yeast pet Mutants

35. Transformation of Nuclear Respiratory Deficient Mutants of Yeast

36. Analysis of Yeast Mitochondrial Genes

37. Genetics and Biogenesis of Cytochrome $b$

38. Synthesis and Intracellular Transport of Mitochondrial Matrix Proteins in Rat Liver: Studies in Vivo and in Vitro

39. Biosynthesis of Cytochrome $c$ and Its Posttranslational Transfer into Mitochondria

40. Isolation of Mammalian Mitochondrial DNA and RNA and Cloning of the Mitochondrial Genome

41. Analysis of Human Mitochondrial RNA

42. Isolation of a Hexokinase Binding Protein from the Outer Mitochondrial Membrane
Helmut Freitag,

ROLAND BENZ, AND

WALTER NeUPERT

SANGKot Marzuki and

ANTHONY W. LINNANE

MORdechai SuISSA AND

Graeme A. Reid

Peter C. Böhni AND

GÜNTher DaUm

Graeme A. Reid

Phyllis C. McAda and Michael G. Douglas

Karen O'Malley and Michael G. Douglas

Carol L. Dieckmann and Alexander TzagolofF

Carol L. Dieckmann and Alexander Tzagoloff

Philip S. Perlman AND Henry R. Mahler

Gordon C. SHORE, Richard A. Rachubinski, Carole Argan, Rima

ROZEN, MARCEL

Pouchelet, Carol J.

LUSTY, AND YVES

RAYMOND

TAKASHI MORIMOTO, Shiro MatsuUra, AND MONIQUE ARPIN

Douglas P. Tapper, Richard A. VAN ETTEN, and David A. Clayton

GIUSEPPE ATtARDI AND JULIO MONTOYA

JOHN E. WILSON, JANICE L. MESSER, AND PHILIP L. FELGNER 
43. Protein Synthesis by Isolated Plant Mitochondria

C. J. Leaver, E. Hack, AND B. G. FORDE

\section{Section III. Chloroplasts}

44. Synthesis and Assembly of Thylakoid Membrane Proteins in Isolated Pea Chloroplasts

Richard S. Williams AND JOHN BENNETT

45. In Vitro Reconstitution of Synthesis, Uptake, and Assembly of Cytoplasmically Synthesized Chloroplast Proteins

46. Structure and Synthesis of Chloroplast ATPase

NATHAN NELSON

47. Cloning in Physical Mapping of Maize Plastid Genes

LAWRENCE BOGORAD,

EARL J. GubBins,

ENNO KREBBERS,

IGNACIO M. LARRINUA,

Bernard J. Mulligan,

KAREN M. T.

MuSKAVITCH,

ElizABETH A. ORR,

STEVEN R. RODERMEL,

RUdi SCHANTZ,

ANDre A. STEINMETZ,

GuIDo De Vos, AND

YUKUN K. YE

48. Role of Thylakoid Polypeptide Phosphorylation and

Turnover in the Assembly and Function of Photo-

M. Wettern, J. C. OWens, system II

AND I. OHAD

Section IV. Summary of Membrane Proteins

49. Membrane Proteins: A Summary of Known Structural Information

David R. Nelson AND

NEAL C. ROBINSON

\section{Addendum}

Addendum to Article [39]

TAKASHi MORIMOTO,

SHIRO MATSUURA, AND

MONIQUE ARPIN

AUthor INDEX . . . . . . . . . . . . . . . . . . . . . . . . . 625

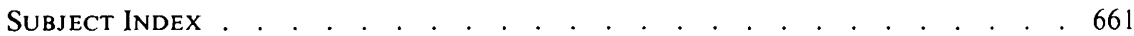




\title{
[27] Isolation and Properties of the Porin of the Outer Mitochondrial Membrane from Neurospora crassa
}

\author{
By Helmut Freitag, Roland Benz, and Walter Neupert
}

The outer mitochondrial membrane is freely permeable to low molecular weight components such as metal ions, substrates, and nucleotides. ${ }^{1.2}$ Therefore pores in the outer membrane have been postulated. The size of these pores is not clearly defined. Molecules with apparent molecular weights up to 2000-8000 were found to permeate through these channels. Detergent extracts of mitochondrial outer membranes or purified pore proteins were incorporated into liposomes or bilayers. Formation of nonspecific pores with a diameter of about $20 \AA$ was observed. ${ }^{3-8}$ The pore-

' R. L. O'Brien and G. Brierley, J. Biol. Chem. 240, 4527 (1965).

2 E. Pfaff, M. Klingenberg, E. Ritt, and W. Vogell, Eur. J. Biochem. 5, 222 (1968).

${ }^{3}$ M. Colombini, Nature (London) 279, 643 (1979).

${ }^{4}$ M. Colombini, J. Membr. Biol. 53, 79 (1980).

${ }^{5}$ L. S. Zalman, H. Nikaido, and Y. Kagawa, J. Biol. Chem. 255, 1771 (1980).

${ }^{6}$ H. Freitag, W. Neupert, and R. Benz, Eur. J. Biochem. 123, 629 (1982).

${ }^{7}$ N. Roos, R. Benz, and D. Brdiczka, Biochim. Biophys. Acta 686, 204 (1982)

${ }^{8}$ H. Freitag, G. Genchi, R. Benz, F. Palmieri, and W. Neupert, FEBS Lett. 145, 72 (1982). 
forming protein, called mitochondrial porin, is a major component of outer mitochondrial membranes. It has an apparent molecular weight of about 31,000 . In many respects the mitochondrial porin resembles the porins of outer membranes from gram-negative bacteria.

Here we describe two different isolation procedures for this protein and discuss some of its properties and its reconstitution into artificial bilayers.

\section{Isolation of Mitochondrial Porin}

Growth of Neurospora crassa hyphae (wild-type 74A) for $17 \mathrm{hr}$ in 8-liter cultures (inoculum $1 \times 10^{6} \mathrm{conidia} / \mathrm{ml}$ ) in the presence of $2 \%$ sucrose and disruption of cells are carried out according to standard procedures. ${ }^{9}$ Mitochondria are isolated in isolation medium $(0.44 \mathrm{M}$ sucrose, $2 \mathrm{~m} M$ EDTA, $30 \mathrm{~m} M$ Tris- $\mathrm{HCl}, \mathrm{pH} 7.6$, adjusted at $4^{\circ}$ ) with the addition of $0.5 \mathrm{mM}$ phenylmethylsulfonyl fluoride (PMSF; final concentration), freshly dissolved in ethanol. The following centrifugation steps are carried out at $4^{\circ}$, employing a Sorvall RC 5B centrifuge and a GS-3 rotor. The cell debris are removed by centrifugation for $20 \mathrm{~min}$ at $2000 \mathrm{~g}$. The resulting supernatant is centrifuged for $45 \mathrm{~min}$ at $17,000 \mathrm{~g}$. The upper layers of the resulting sediment (containing the mitochondria) are washed twice by resuspending them in a glass-Teflon potter and centrifuging for $45 \mathrm{~min}$ at $17,000 \mathrm{~g}$. The final mitochondrial pellet is the starting material for the porin isolation. Under typical conditions, from an 8-liter culture of Neurospora crassa $180 \mathrm{~g}$ of hyphae (wet weight) are obtained and the yield of mitochondria is $230 \mathrm{mg}$ protein.

\section{Porin Isolation from Outer Membranes ${ }^{6}$}

\section{Principle}

Mitochondrial outer membranes are isolated by swelling-shrinking of the mitochondria and subsequent separation by a sucrose step centrifugation. Differential detergent extraction of the outer membrane followed by DEAE-cellulose chromatography gives pure porin, which forms active pores after reconstitution into artificial bilayers.

\section{Reagents}

Swelling medium: $2.5 \mathrm{mM}$ potassium $\mathrm{H}_{2} \mathrm{PO}_{4}$, adjusted to $\mathrm{pH} 7.3$ with $\mathrm{KOH}$

PMSF stock solution: $100 \mathrm{~m} M$ PMSF in ethanol, freshly prepared

Shrinking medium: $2.2 M$ sucrose, $8 \mathrm{mM} \mathrm{MgCl}_{2}, 8 \mathrm{~m} M$ ATP, adjusted to pH 7.3 with $\mathrm{KOH}$

${ }^{9}$ W. Neupert and G. D. Ludwig, Eur. J. Biochem. 19, 523 (1971). 
Isolation medium: $0.44 M$ sucrose, $2 \mathrm{~m} M$ EDTA, $30 \mathrm{~m} M$ Tris- $\mathrm{HCl}, \mathrm{pH}$ 7.5

Sucrose step medium: $0.95 M$ sucrose, $10 \mathrm{~m} M$ Tris- $\mathrm{HCl}$, pH 7.5

Tris buffer: $10 \mathrm{~m} M$ Tris- $\mathrm{HCl}, \mathrm{pH} 7.5$

Phosphate buffer: $100 \mathrm{mM}$ potassium $\mathrm{H}_{2} \mathrm{PO}_{4}$, adjusted to $\mathrm{pH} 7.3$ with $\mathrm{KOH}$

Octyl glucoside solution: $60 \mathrm{~m} M$ octyl- $\beta$-D-glucoside, $5 \mathrm{~m} M$ Tris- $\mathrm{HCl}$, pH 7.5 (17.5 mg of octyl glucoside per milliliter)

Genapol solution: 1\% Genapol X-100 (Farbwerke Hoechst, Frankfurt, FRG), $5 \mathrm{~m} M$ Tris-HCl, pH 7.5. Genapol X-100 contains polyethoxy chains like Triton X-100, but has isotridecyl groups instead of aromatic rings and therefore shows no absorption at $280 \mathrm{~nm}$

DEAE-cellulose column: A column ( $15 \mathrm{ml}, 1 \mathrm{~cm}$ diameter $)$ is filled with DEAE-cellulose (DE-52, Whatman, Maidstone, England) and equilibrated with the Genapol solution. The flow rate was $10 \mathrm{ml} / \mathrm{hr}$. In all solutions, the $\mathrm{pH}$ was adjusted at $4^{\circ}$.

\section{Procedure}

Isolation of Outer Membranes. Swelling solution, $100 \mathrm{ml}$ containing $0.5 \mathrm{~m} M$ PMSF is used for $100 \mathrm{mg}$ of mitochondrial protein. The mitochondrial pellet is suspended in the swelling medium with a glass-Teflon potter. The suspension is stirred for $15 \mathrm{~min}$ at $4^{\circ}$, and then $70 \mathrm{ml}$ of the shrinking medium are added while stirring. During shrinking the suspension becomes more turbid. It is further stirred for $10 \mathrm{~min}$. Then $60-\mathrm{ml}$ portions of the suspension are transferred into a glass - teflon potter, and the pestle, driven by a motor at $500-700 \mathrm{rpm}$, is moved up and down five times. The membranes are then pelleted by centrifugation for $45 \mathrm{~min}$ at $98,000 \mathrm{~g}$ in a Beckman ultracentrifuge using a $45 \mathrm{Ti}$ rotor. The pellets are suspended in isolation medium with a glass-Teflon potter, then $35 \mathrm{ml}$ of the sucrose step medium are filled into a Beckman SW 25.2 centrifuge tube and overlayered with $20 \mathrm{ml}$ of the mitochondrial suspension, containing the membranes from about $100 \mathrm{mg}$ of mitochondria. Centrifugation is performed for $60 \mathrm{~min}$ at $70,000 \mathrm{~g}$. The small band of red outer membranes on top of the $0.95 M$ sucrose solution is collected with a bended Pasteur pipette. The suspension is diluted with an equal volume of Tris buffer and centrifuged for 30 min at $166,000 \mathrm{~g}$ in a Beckman 50 Ti rotor. The outer membrane pellets are suspended in phosphate buffer with the addition of $8 \%$ dimethyl sulfoxide $(\mathrm{v} / \mathrm{v})$ at a protein concentration of $3.5 \mathrm{mg} / \mathrm{ml}$ and stored in $-20^{\circ}$. The yield of outer membranes is about $0.5 \%$ of protein with respect to whole mitochondria, which is about $25 \%$ of the theoretical amount. Samples should be stored not longer than 1 week, because prolonged storage alters the behavior of the membranes during the subsequent extraction procedures. 
Isolation of Porin. The thawed suspension of outer membranes is first extracted with octyl glucoside, which removes most of the outer membrane proteins, except the porin. ${ }^{6}$ For this extraction it is important to adjust the octyl glucoside concentration to $30 \mathrm{~m} M$, and the octyl glucoside-to-protein ratio to $10(\mathrm{w} / \mathrm{w})$, to obtain reproducible results. One milliliter of outer membrane suspension is first diluted with phosphate buffer to $2 \mathrm{ml}$, then $2 \mathrm{ml}$ of $60 \mathrm{~m} M$ octyl glucoside solution are added. The mixture is kept at $4^{\circ}$ for $45 \mathrm{~min}$. Then it is transferred into Eppendorf tubes, which are placed in water-filled plastic adaptors and centrifuged for $30 \mathrm{~min}$ at $150,000 \mathrm{~g}$ in a Beckman $50 \mathrm{Ti}$ rotor. The membrane pellets are suspended in the Genapol solution by adding $1 \mathrm{ml}$ per milligram of the original outer membrane protein. They are shaken for $30 \mathrm{~min}$ at $4^{\circ}$. After centrifugation in an Eppendorf centrifuge for $5 \mathrm{~min}$, the supernatant is subjected to chromatography on a DEAE-cellulose column, equilibrated with the Ganapol solution. Elution is followed by monitoring the absorbance at $280 \mathrm{~nm}$. The protein that elutes with the void volume is pure porin and can be stored for several months at $-20^{\circ}$.

\section{Porin Isolation from Whole Mitochondria ${ }^{8}$}

\section{Principle}

Whole mitochondria are lysed with Genapol X-100 and chromatographed on hydroxyapatite, Celite, and DEAE-cellulose. This procedure gives pure and functionally active porin in high yield and can be easily scaled up.

\section{Reagents}

Buffer A: $2.5 \%$ Genapol X-100 (Farbwerke Hoechst, Frankfurt, Federal Republic of Germany), $50 \mathrm{mM} \mathrm{KCl}, 10 \mathrm{mM}$ potassium $\mathrm{H}_{2} \mathrm{PO}_{4}, 1 \mathrm{mM}$ EDTA, $10 \mathrm{~m} M$ Tris adjusted to $\mathrm{pH} 7.0$ with $\mathrm{HCl}$

Genapol solution: $1 \%$ Genapol X-100, $5 \mathrm{~m} M$ Tris- $\mathrm{HCl}, \mathrm{pH} 7.5$

Dry hydroxyapatite (BioGel HTP, Bio-Rad, Richmond, California)

Dry Celite (Celite 535, Roth, Karlsruhe, Federal Republic of Germany).

\section{Procedure}

For this isolation procedure, frozen mitochondria can be used. Two Pasteur pipettes plugged with cotton wool, one filled with $0.6 \mathrm{~g}$ of hydroxyapatite and the other filled with $0.6 \mathrm{~g}$ of a dry mixture of equal weights of hydroxyapatite and Celite, are prepared. To $4-6 \mathrm{mg}$ of protein of a mitochondrial pellet, $0.7 \mathrm{ml}$ of buffer A are added, mixed, and kept for $30 \mathrm{~min}$ at $4^{\circ}$, followed by centrifugation for $15 \mathrm{~min}$ at $27,000 \mathrm{~g}$. The supernatant is applied to the hydroxyapatite pipette. When the solution has entered the 
column, further buffer is applied until the eluate has reached the original volume $(0.7 \mathrm{ml})$. This eluate is transferred to the hydroxyapatite-Celite pipette. Again $0.7 \mathrm{ml}$ of the eluate is collected, which already contains the largely enriched porin. ${ }^{8}$ The eluate is dialyzed overnight against 20 volumes of the Genapol solution and subjected to chromatography on DEAEcellulose as described before.

There are two ways to scale up the isolation procedure. For up to $200 \mu \mathrm{g}$ of porin it is recommended to use 10 Pasteur pipettes in parallel and to combine the eluates for one DEAE-cellulose column of the size described above. In order to prepare porin in larger amounts, larger columns should be used. Mitochondria (1.2 $\mathrm{g}$ of protein) are dissolved in $130 \mathrm{ml}$ of buffer A and chromatographed on columns containing $600 \mathrm{~g}$ of hydroxyapatite or hydroxyapatite-Celite mixture (diameter $3 \mathrm{~cm}$ ) and over a DEAE-cellulose column of $40 \times 3 \mathrm{~cm}$. The yield is $3-4 \mathrm{mg}$ of porin.

\section{Comment}

The porin contains an acid-labile bond. ${ }^{8}$ Precipitation of porin from detergent-containing solutions with acids should be carried out in the cold. Add one-tenth volume of $3 \mathrm{M}$ trichloroacetic acid and one-third volume of methanol (to prevent precipitation of the detergent). After $1 \mathrm{hr}$ at $0-4^{\circ}$ the porin can be separated by centrifugation.

\section{Properties of the Mitochondrial Porin}

\section{General Properties}

The mitochondrial porin $\left(M_{\mathrm{r}} 31,000\right)$ is the major protein of the outer membrane. It represents about $20 \%$ of total outer membrane protein and $0.4 \%$ of total mitochondrial protein. Upon isoelectric focusing, and purified porin gives two bands with pIs of 7.7 (major band) and $7.8 .^{8}$ The reason for this heterogeneity is not known, but porins from other sources also show this behavior. ${ }^{10,11}$

From protease digestion experiments ${ }^{6}$ and from $\mathrm{x}$-ray diffraction data, ${ }^{12}$ it was concluded that the porin is deeply embedded into the membrane and does not extend into the aqueous phase.

It has been demonstrated that the mitochondrial hexokinase binding protein, which binds brain hexokinase ${ }^{12 a}$ or hexokinase from fast growing tumor cells, ${ }^{13}$ is identical with the mitochondrial porin. ${ }^{11,14}$

${ }^{10}$ H. Tokunaga, M. Tokunaga, and T. Nakae, Eur. J. Biochem. 95, 433 (1979).

1 M. Linden, P. Gellerfors, and B. D. Nelson, FEBS Lett. 141, 189 (1982).

${ }^{12}$ C. A. Mannella, Biochim. Biophys. Acta 645, 33 (1981).

12a J. E. Wilson, J. L. Messer, and P. L. Felgner, this volume [42]. 


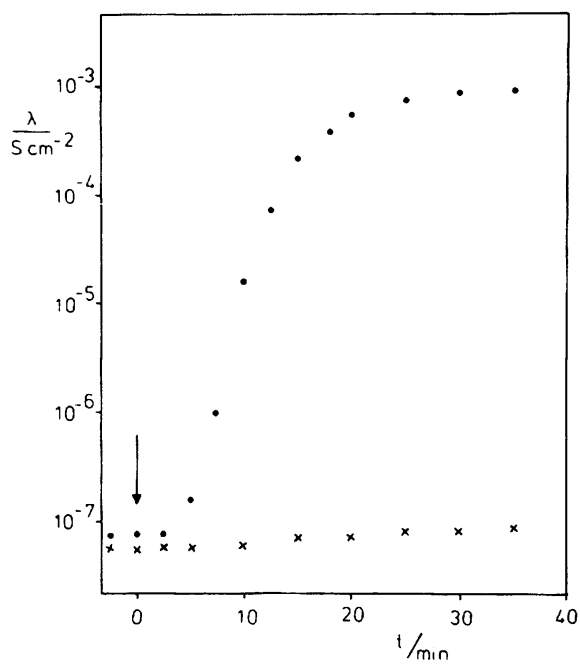

FIG. 1. Specific membrane conductance $\lambda$ as a function of time after addition of $100 \mathrm{ng}$ of mitochondrial porin from Neurospora crassa per milliliter to a black lipid bilayer membrane from asolectin- $n$-decane (arrow). The crosses represent a control experiment where only $10 \mu \mathrm{g}$ of Genapol X-100 per milliliter were added to another membrane; $1 \mathrm{M} \mathrm{KCl}, \mathrm{pH} 6$; $T=25^{\circ}$.

\section{Biosynthesis of the Porin ${ }^{15}$}

Mitochondrial porin is synthesized on cytoplasmic free polysomes without an additional presequence. In contrast to the biogenesis of mitochondrial inner membrane or matrix proteins, ${ }^{16}$ assembly of the porin is not dependent on energization of the mitochondria. By digitonin treatment it could be shown that the porin precursor in an in vitro transfer assay is incorporated into the outer membrane. Binding to the outer membrane precedes the incorporation into this membrane. ${ }^{15}$

\section{Reconstitution of the Porin in Lipid Bilayer Membranes}

The addition of small quantities of mitochondrial porin to the aqueous phase bathing a black lipid bilayer membrane prepared according to established procedure ${ }^{17}$ results in a strong increase of the membrane conductance. A typical experiment is given in Fig. 1. Mitochondrial porin was added in a final concentration of $100 \mathrm{ng} / \mathrm{ml}$ to a black membrane from

\footnotetext{
${ }^{13}$ E. Bustamente, H. P. Morris, and P. L. Pedersen, J. Biol. Chem. 254, 8699 (1981).

${ }^{14}$ C. Fiek, R. Benz, N. Roos, and D. Brdiczka, Biochem. Biophys. Acta 688, 429 (1982).

${ }^{15}$ H. Freitag, M. Janes, and W. Neupert, Eur. J. Biochem. 126, 197 (1982).

${ }^{16}$ M. Schleyer, B. Schmidt, and W. Neupert, Eur. J. Biochem. 125, 109 (1982).

17 R. Benz, K. Janko, W. Boos, and P. Läuger, Biochim. Biophys. Acta 511, 305 (1978).
} 
asolectin - $n$-decane. After an initial lag of about $5 \mathrm{~min}$, presumably caused by the diffusion of the protein through unstirred layers, the conductance increased by about four orders of magnitude within about $30 \mathrm{~min}$. Only a slight further increase occurred after that time. The conductance increase was approximately linearly dependent on the protein concentration in the aqueous phase if the same times after addition of the protein were considered (usually 20-30 min).

A considerable asymmetry of the action of the voltage on the single conductive unit was observed, if the protein was added to only one side of the membrane. ${ }^{6,7}$ This indicates an asymmetric insertion of the protein into the membrane.

Figure 2 shows fluctuations of current observed with mitochondrial porin inserted into a asolectin membrane in the presence of $1 \mathrm{M} \mathrm{KCl}$. Most of the fluctuations were directed upward, and terminating steps were only rarely observed at a membrane voltage of $5-10 \mathrm{mV}$ membrane potential. ${ }^{6}$ This indicated that the lifetime of the pores was long at low voltage and usually exceeded $5 \mathrm{~min}$.

The single conductance increment was fairly uniform in size at a membrane voltage of $5-10 \mathrm{mV}$ (Fig. 3).

Lifetime and single-channel conductance were strongly dependent on the membrane potential. Whereas the single channel conductance $\Lambda$ was about $4.5 \mathrm{nS}$ at $5 \mathrm{mV}(1 \mathrm{M} \mathrm{KCl})$, it decreased at $50 \mathrm{mV}$ to about $0.7 \mathrm{nS} .^{6}$

The conductance of the mitochondrial porin is comparable to that of the bacterial porins under otherwise identical conditions. Assuming that the pores are filled with a solution of the same specific conductivity $\sigma$ as the

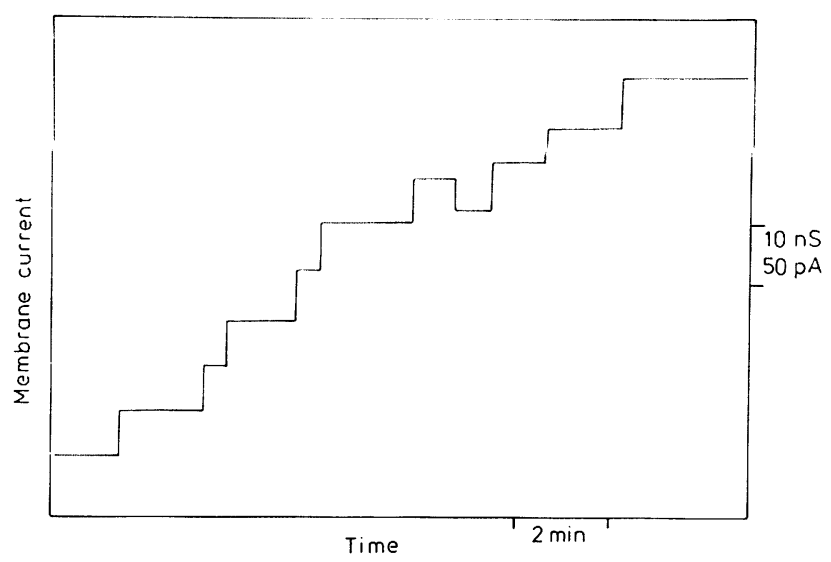

FIG. 2. Stepwise increase of the membrane current in the presence of $5 \mathrm{ng}$ of mitochondrial porin per milliliter from Neurospora crassa added to the aqueous phase containing $1 \mathrm{M} \mathrm{KCl}$; $T=25^{\circ}$. The membrane was formed from asolectin- $n$-decane; $V_{\mathrm{m}}=5 \mathrm{mV}$. 


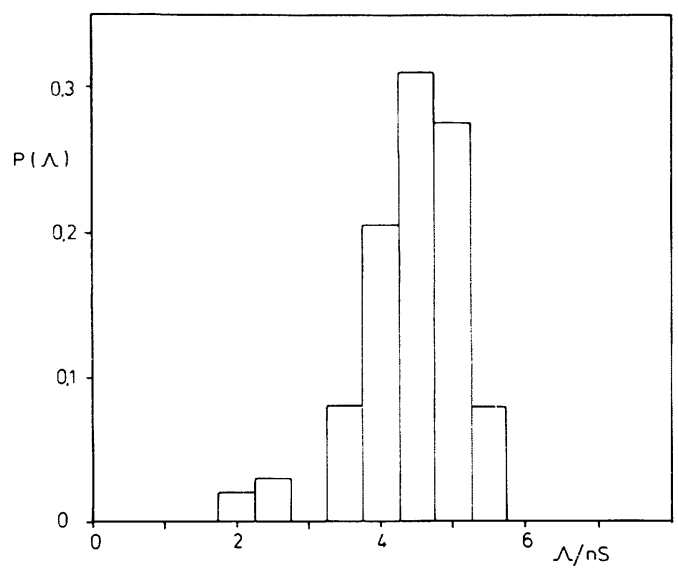

FIG. 3. Histogram of the conductance fluctuations observed with membranes from asolectin- $n$-decane in the presence of mitochondrial porin from Neurospora crassa. The aqueous phase contained $1 \mathrm{M} \mathrm{KCl} ; \mathrm{pH} 6 ; T=25^{\circ}$. Applied voltage was $5 \mathrm{mV}$; the mean value of all observed conductance fluctuations was $4.5 \mathrm{nS}$ for 253 single events.

external solution and assuming a pore length $7.5 \mathrm{~nm}$ (corresponding to the thickness of the outer membranes of bacteria and mitochondria), the average pore diameter $d(=2 r)$ and the cross section can be calculated according to the equation $\Lambda=\sigma \pi r^{2} / l$. The table shows the diameter and the cross section for mitochondrial porins from Neurospora crassa and rat liver, as well as for the bacterial porins from different gram-negative bacteria. ${ }^{6.7,17-21}$

${ }^{18}$ R. Benz and R. E. W. Hancock, Biochim. Biophys. Acta 646, 298 (1981).

${ }^{19}$ R. E. W. Hancock, G. M. Decad, and H. Nikaido, Biochim. Biophys. Acta 554, 323 (1979).

${ }^{20}$ H. Nikaido and T. Nakae, Adv. Microbiol. Physiol. 20, 163 (1979).

${ }^{21}$ R. Benz, J. Ishii, and T. Nakae, J. Membr. Biol. 56, 19 (1980).

COMPaRISON OF the PORES FORMED by MitochondRIAL AND

BaCterial PORINS IN LiPID BILAYer MEMBRANE ${ }^{a}$

\begin{tabular}{lcccc}
\hline \multicolumn{1}{c}{ Porin } & $\begin{array}{c}\Lambda \\
(\mathrm{nS})\end{array}$ & $\begin{array}{c}d \\
(\mathrm{~nm})\end{array}$ & $\begin{array}{c}\text { Area } \\
\left(\mathrm{nm}^{2}\right)\end{array}$ & $\begin{array}{c}\text { Reference } \\
\text { footnote }\end{array}$ \\
\hline $\begin{array}{l}\text { Mitochondrial } \\
\quad \text { Neurospora crassa }\end{array}$ & & & & \\
$\quad \begin{array}{l}\text { Rat liver } \\
\text { Bacterial }\end{array}$ & 4.5 & 2.0 & 3.1 & 6 \\
$\quad \begin{array}{l}\text { Escherichia coli } \\
\text { Salmonella typhimurium }\end{array}$ & 4.3 & 1.9 & 2.9 & 7 \\
$\quad$ Pseudomonas aeruginosa & 1.9 & 1.3 & 1.3 & 17 \\
\hline
\end{tabular}

"The pore diameter $d$ was calculated from the pore conductance in $1 \mathrm{M} \mathrm{KCl}$ according to $\Lambda=\sigma \pi r^{2} / l$ (using $\sigma=110 \mathrm{mS} \mathrm{cm}^{-1}$ and length $(l)=7.5 \mathrm{~nm}$ ). 
The diameter of the pore from Pseudomonas aeruginosa protein $\mathrm{F}$ is about the same as that of the mitochondrial porin pores. ${ }^{18}$ This is consistent with the observations on the pores in reconstituted vesicles, which in both cases were permeable to hydrophilic solutes of molecular weights up to $6000 .^{5,19}$ 